\title{
Development of Supervision Instrument Application Model through the Utilization of Android-Based Technology for School Heads
}

\author{
Risa Fahriyani Purnamawati ${ }^{1}$, Rais Hidayat $^{2}$, Henny Suharyati $^{3, *}$ \\ ${ }^{1,2,3}$ Educational Administration Study Program, postgraduate of Universitas Pakuan, Bogor, Indonesia \\ *Corresponding author email: henny.suharyati@unpak.ac.id
}

\begin{abstract}
Indonesia needs to improve the teacher's competence in terms of personality, social, pedagogic and professional dimension since the student's achievement is still under satisfied. Learning supervision is one of the competences which the principal should have to improve the teacher's performance. Observation and data analysis of the learning supervision are the important components to create such qualified information. The research is intended to develop manual based observation to be Android based observation by research and development method, to analyze and empirically proof the model quality and accountability. The research fact of model quality is based on the assessment of supervision, output, linguistics, usage, software engineering, design, and visual communication aspects. Data analyzing technique uses qualitative approach through inductive method while data collecting technique uses observation model of 11 principals research subject at Gugus 04 of District Cisarua Kabupaten Bogor. The research produce Android based observation namely AOS (Application of Observation) with the accountability index 4.57 which means that the model is $\backslash$ accountable to be used at learning supervision process so that the quality of the learning process and the student performance can be improved.
\end{abstract}

Keywords: Application of observation; learning supervision; student's achievement; teacher competence; quality of the learning process

\section{Introduction}

Learning supervision is one of the competencies that the principal must have because it plays a very strategic role in increasing the competence of educators in the personality, social, pedagogic, and professional dimensions (Pratiwi et al., 2020; Anggraeni et al., 2020). Increasing the competence of educators can be seen through improving the quality of the education process and the learning outcomes of students.

The results of formal and informal discussions during the implementation of training for principals and prospective school principals specifically for academic supervision (learning), many principals and teachers rarely supervise or be supervised, for various reasons (Thakral, 2015; Wahyu, 2020), so it is not surprising that the quality of education in Indonesia is considered very low.

According to UNESCO, supervision activities are proven to have a positive impact on improving student achievement (McCallin and Nayar, 2012). Thus, effective learning supervision services should be part of routine activities in schools, thus developing teacher competence can be a continuous activity. There are three stages or episodes in the implementation of learning supervision, namely: (1) initial meeting episodes, (2) classroom observation episodes, and (3) feedback encounters (Makin et al., 2018).

UNESCO recommends three important components that must be fulfilled in the supervision process to get quality output, namely information gathering; information analysis; and follow-up (Lessing and Schulze, 2002). The three components recommended by UNESCO above are at the observation stage, namely the observation stage on supervisees.

Currently, the results of observations (observations) in the learning supervision process are collected and processed using various models, including manual (paper) models, Microsoft Excel application models, or web-based services. Each of these models has advantages and disadvantages that affect the effectiveness of the learning supervision process. 
At the same time, the global industry is moving very fast to encourage the birth of the industrial revolution 4.0, so that the challenges for the government in developing education are becoming increasingly complex. As a roadmap to Industry 4.0, President Joko Widodo at the opening of the 2018 Indonesia Industrial Summit at the Jakarta Convention Center, Senayan, Central Jakarta, on Wednesday, April 4, 2018, formalized Indonesia's strategy for entering Industry 4.0 initiated by the Ministry of Industry with the name "Making Indonesia 4.0". This strategy was then accompanied by the Education 4.0 program as a consequence of preparing human resources. In line with this idea, the holding of the International Symposium on Open, Distance and E-Learning 2018 (ISODEL) which will be held from 3-5 December, 2018, in Bali, resulted in 22 conclusions and 20 recommendations to realize "Education 4.0 for Indonesia". The 12th point of the recommendation is to improve the education ecosystem through the use of information and computer technology (ICT) for multi-sector stakeholders.

Given the increasing number of Android technology users in Indonesia (https://datareportal.com/reports/digital2020-indonesia), and media for storing or sending data to be relatively affordable and of high quality, recommendations to improve the education ecosystem through the use of technology are something which is not impossible to be realized, including the learning supervision activities.

Android is a Java-based operating system that runs on the Linux 2.6 kernel. This system is very light and fully featured (Felker, 2010) which can be run on gadgets such as mobile phones, smartphones, and tablets. With the opensource distribution system used by Android, it allows developers to create various interesting applications. Because of this, Android developers are free to create applications that take full advantage of mobile hardware so that they can take advantage of unique features to improve existing products or create new and innovative ones (Meier, 2012).

Based on the description above and the facts in the field, this research is intended to develop an observation application model through the use of Android-based technology to increase the effectiveness of the learning supervision process.

\section{Methodology}

This type of research is research and development (Research and Development) with the theory of Borg and Gall which is modified from 10 (ten) steps to 9 (nine) steps as needed. This study used a qualitative approach, with inductive methods for data analysis carried out on 11 primary school principals in cluster 04, Cisarua District, Bogor Regency.

The type of data used in this research is primary data. Primary data used comes from a questionnaire after the research subjects used the observation application.

The data analysis methods used are as follows:

1. Changing a qualitative assessment to a quantitative one with the provisions that can be seen in Table 1 .

2. Calculating the average score for each indicator with the formula:

$$
\bar{\chi}=\frac{\sum \chi}{\mathrm{N}}
$$

Information:

$$
\begin{array}{ll}
\bar{\chi} & =\text { average score } \\
\sum \chi & =\text { total score } \\
\mathrm{N} & =\text { the number of test subjects }
\end{array}
$$

The collected average score data is converted into qualitative values with the following predetermined criteria. The ideal assessment criteria can be seen in Table 1 .

Table 1. Ideal assessment criteria

\begin{tabular}{cccc}
\hline Value & Score Range & Average Score & Category \\
\hline A & $\mathrm{X}>\overline{\mathrm{X}} \mathrm{i}+1.8 \times$ sdi & $\mathrm{X}>4.2$ & Very worthy \\
$\mathrm{B}$ & $\overline{\mathrm{X}} \mathrm{i}+0.6 \times \operatorname{sid}<\mathrm{X} \leq \overline{\mathrm{X}} \mathrm{i}+1.8 \times$ sid & $34<\mathrm{X} \leq 4.2$ & Worthy \\
$\mathrm{C}$ & $\overline{\mathrm{X}} \mathrm{i}-0.6 \mathrm{xid}<\mathrm{X} \leq \overline{\mathrm{X}} \mathrm{i}+0.6 \times$ sid & $2.6<\mathrm{X} \leq 3.4$ & Fair \\
$\mathrm{D}$ & $\overline{\mathrm{X}} \mathrm{i}-1.8 \times \mathrm{xid}<\mathrm{X} \leq \overline{\mathrm{X}} \mathrm{i}-0.6 \times$ sid & $1.8<\mathrm{X} \leq 2.6$ & Less \\
$\mathrm{E}$ & $\mathrm{X} \leq \overline{\mathrm{X}} \mathrm{i}-1.8 \times$ sid & $\mathrm{X} \leq 1.8$ & Very Inadequate \\
\hline
\end{tabular}


Information:

$\mathrm{X}=$ average Score

$\overline{\mathrm{X}} \mathrm{i} \quad=$ ideal average

$=1 / 2$ (ideal maximum score + ideal minimum score)

isd $\quad=$ Ideal standard deviation

$=1 / 6$ ideal maximum score - ideal minimum score)

To determine the quality of the media product being developed is feasible or not, the researcher uses the minimum assessment criteria which is included in the "Good" category. If the minimum application appraisal gets a "Good" value, then the application developed "Feasible" is used as an observation application in the learning supervision process.

\section{Results}

By using the borg and gall research and development method the following results were obtained:

\subsection{Research and information collecting}

From the preliminary research conducted through a questionnaire on February 25, 2019, to 15 primary school principals in cisarua district, it is known that $100 \%$ use the manual (paper) observation model, although 33.3\% admit to being constrained by costs in procuring paper media and $53.3 \%$ is constrained by filling in the observation instrument.

Time range required for observation: $28.6 \%$ between 60 minutes-120 minutes, $50 \%$ between 30 minutes to 60 minutes, and $14 \%$ claimed more than two hours for one observation, and the rest claimed to be under 30 minutes, however, 73.3\% admitted that they were constrained by the length of the process of filling the learning supervision instruments, and 66.7 were constrained by the length of the process of calculating the results of observations.

Then it was also discovered that $100 \%$ of school principals have android-type mobile phones and $92.3 \%$ use cell phones more than using laptops. 93.3\% gave a positive response to the plan for an android-based observation application and the rest were neutral. Those who give a positive response hope that the application will be easy to use, provide accurate observation results, and can speed up the supervision process.

\subsection{Planning}

Based on the potential and known problems from the previous stage, the following are the criteria for the planned Android-based observation application:

a. Applications can be used anywhere and anytime via an Android smartphone with an internet connection

b. Applications can guarantee the speed and accuracy of data processing

c. The application provides complete results or reports that the supervisor can immediately see and know the recapitulation, including notes for follow-up.

d. Users can immediately see the instruments and the results of the supervision that has been carried out.

\subsection{Develop a preliminary form of product (development of initial product designs)}

Initial product development requires a system design process, user experience / ui design, and coding. The term of scoring can be seen in Table 2 .

Table 2. Terms of scoring

\begin{tabular}{lc}
\hline \multicolumn{1}{c}{ Category } & Score \\
\hline SA (Strongly Agree) & 5 \\
A (Agree) & 4 \\
D (Disagree) & 3 \\
D (Disagree) & 2 \\
SD (Strongly Disagree) & 1 \\
\hline
\end{tabular}


The design carried out is as follows:

\section{a. Design system}

System design (system design) is made in such a way that it is suitable for object-oriented (oo) based software by using unified modeling language (uml) as a tool for creating blueprint software (Siau et al., 2005). The manufacturing steps refer to the iconix process technique (Mukaromah et al., 2018; Pratama et al., 2020). The process of designing an application system is needed to transform user requirements, both functionally and non-functional into a model. The resulting products from system design are functional requirements (defining what the application is designed can do), domain models (data configuration, and function to equate terms), use case diagrams (who uses the system and what it can do), and sequence diagrams (diagrams that describe object interactions and indicate communication between these objects).

\section{b. User expression (ux) design and user interface (ui) design}

Ux / ui design refers to the concept of user-centered design (ucd) (Kim, 2018). The ux design stage produces a wireframe (Garrett, 2006), mockup, and prototype (Saideian and Dale, 2000). In the ui design process, the screen layout design was carried out (Galitz, 2002). This stage produces the ui-guideline for the observation application.

\section{c. Coding (programming code generation)}

At the coding stage, object-oriented applications can use the mit app inventor with data storage on google sheet (Liu et al., 2012) and navigated by google apps script (White and Allen, 2014).

At this stage, the researcher converts the paper prototype into a digital prototype by coding (programming code). The product of this stage is a digital prototype with the name aos prototype.

\subsection{Preliminary field testing}

At this stage, the researcher conducted an initial field test through the usability testing process using a paper prototype to test the level of ease of interaction between the user and the application.

Usability testing was carried out on 5 testers consisting of 1 principal, 1 vice principal, and 3 senior teachers. Then the results of usability testing are entered into the completion rate form can be seen in Table 3.

Tabel 3. Usability Testing Result

\begin{tabular}{|c|c|c|c|c|c|}
\hline & STEP 1 & STEP 2 & STEP 3 & STEP 4 & STEP 5 \\
\hline User 1 & 0 & O & $\theta$ & 0 & • \\
\hline User 2 & 0 & 0 & 0 & 0 & $\theta$ \\
\hline User 3 & 0 & 0 & 0 & 0 & $\theta$ \\
\hline User 4 & 0 & 0 & 0 & 0 & P \\
\hline User 5 & 0 & 0 & 0 & 0 & 0 \\
\hline
\end{tabular}

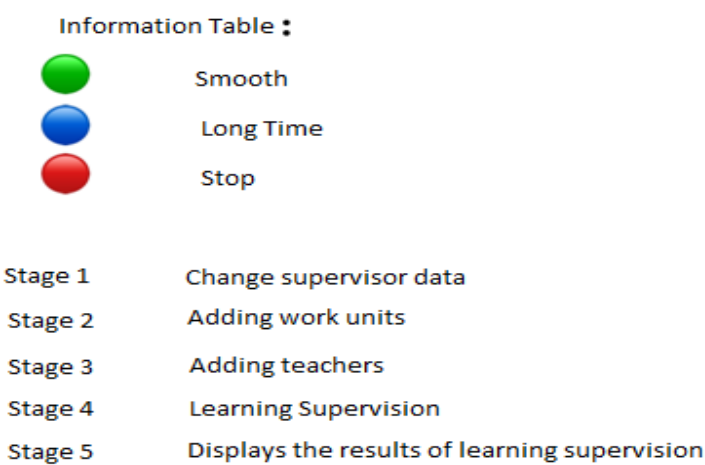

From the Table 3, the researcher concludes that the tester can interact with the application smoothly so that the researcher can conclude that the workflow and navigation system are not problematic.

\subsection{Main product revision}

Based on the results of usability testing above, the researcher did not make changes to the main flow and navigation system of the application, but the researcher made revisions to the typing and spelling errors.

\subsection{Main field testing}

Furthermore, the researcher conducted the main field test. This test was carried out on June 5 and June 9, 2020 to 2 objects (the principal of sdn kopo 03 cisarua and the principal of SDIT Darul Fallah) using a prototype version of the 
observation application and a questionnaire. Filling the questionnaire is done after the respondent uses the observation application. The Limited test results can be seen in Table 4.

Table 4. Limited test results

\begin{tabular}{cccc}
\hline Indicator & Total Score & Average Score & Category \\
\hline Material Aspect & 84 & 4.20 & Very worthy \\
Results Aspect & 70 & 4.38 & Very worthy \\
Language Aspect & 18 & 4.50 & Very worthy \\
Aspects of Implementation & 63 & 4.50 & Very worthy \\
Software Engineering Aspects & 91 & 4.55 & Very worthy \\
Design Aspects & 18 & 4.50 & Very worthy \\
Visual Communication Aspects & 9 & 4.50 & Very worthy \\
Total & $\mathbf{3 5 3}$ & $\mathbf{4 . 4 5}$ & Very worthy \\
\hline
\end{tabular}

\subsection{Final Product Revision (Revision of the final product)}

At this stage, the researcher made a final revision of the user interface (fonts, typography, and colors), and created a guide for using the application. The product resulting from this process is an observation application (See Figure 1).

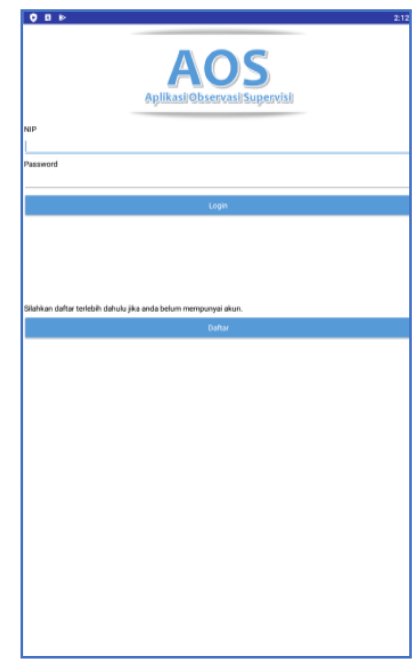

\begin{tabular}{|c|c|c|}
\hline \multicolumn{3}{|l|}{ Hasil } \\
\hline NIP & \multicolumn{2}{|l|}{$: 111$} \\
\hline Nama & \multicolumn{2}{|c|}{ : Lyna Novianti } \\
\hline \multicolumn{3}{|c|}{ Mata Pelajaran : Matematika } \\
\hline Unit Kerja & \multicolumn{2}{|c|}{ : SDIT DATUL FALLAH } \\
\hline No HP & \multicolumn{2}{|l|}{$: 123$} \\
\hline Email & \multicolumn{2}{|c|}{ : Lyna@gmail.com } \\
\hline \multicolumn{3}{|c|}{ :2020-6-21 } \\
\hline \multicolumn{3}{|c|}{ No Komponen Skor Persen } \\
\hline A Pendahuluan & 25 & $89 \%$ \\
\hline B Kegiatan Inti & 28 & $100 \%$ \\
\hline c Penilaian & 12 & $100 \%$ \\
\hline D Penutup & 28 & $100 \%$ \\
\hline \multicolumn{3}{|l|}{ Skor Akhir : 93} \\
\hline \multicolumn{3}{|c|}{ Predikat : Baik Sekali } \\
\hline Kembali & & Selanjutny \\
\hline
\end{tabular}

Figure 1. Part of the AOS.apk display

\section{8. Feasibility test}

Content validation is used to assess whether the content has been compiled in the learning supervision observation application. The content validation was carried out by Drs. Adnawijaya, MM. as the Head of the Coordinator of Formal and Non-Formal Education Services, Cisarua District, Bogor Regency, and the supervision expert in this study. The validation technique was carried out using a Likert-scale questionnaire with five alternative answer choices. The questionnaire for media experts has 17 assessment indicators which are grouped into 4 aspects, namely the aspect of supervision, aspects of results, aspects of language, and aspects of implementation. The validation results as shown in Table 5.

Table 5. The results of the supervision expert validation

\begin{tabular}{lccc}
\hline \multicolumn{1}{c}{ Aspects } & Total Score & Average & Category \\
\hline Aspects of Learning Supervision Objectives & 49 & 4.90 & Very worthy \\
Results Aspects & 39 & 4.88 & Very worthy \\
Language Aspect & 10 & 5.00 & Very worthy \\
Aspects of Implementation & 33 & 4.71 & Very worthy \\
Supervision Validation Index & & $\mathbf{4 . 8 7}$ & Very worthy \\
\hline
\end{tabular}


Media validation is carried out to assess and assess whether the media being developed is feasible to be tested. Media validation was carried out on June 10, 2020, by Mr. Ir. Mochamad Taufik is an IT (Information Technology) Professional as a media expert. The validation technique is carried out using a Likert-scale questionnaire with five alternative answer choices. The questionnaire for media experts has 20 assessment indicators which are grouped into 3 aspects, namely aspects of software engineering, aspects of design, and aspects of visual communication. The questionnaire was filled out after the media expert tried to use the prototype version of the observation application (See Table 6).

Table 6. Results of the media expert validation

\begin{tabular}{lccc}
\hline \multicolumn{1}{c}{ Aspects } & Total Score & Average & Category \\
\hline Software Engineering Aspects & 63 & 4.85 & Very worthy \\
Design Aspects & 23 & 4.60 & Very worthy \\
Visual Communication Aspects & 9 & 4.50 & Very worthy \\
Supervision Validation Index & & $\mathbf{4 . 6 5}$ & Very worthy \\
\hline
\end{tabular}

In the media feasibility process, media experts provide the following suggestions: In the application usage instructions, it must be explained about the need for a Google user account to have sufficient capacity on the Google server to prevent I / O errors. The instructions for using the application must explain to the user that the remaining space on the Android system is not less than 500MB for the application's work space to prevent crashes. and if you want to add a feature to import data sheets from USB or Removable media, the file must be in a standard format that can be read by the Android system.

\subsection{Dissemination and implementation (Dissemination and implementation)}

The implementation stage was carried out on 19-24 June 2020 by conducting trials with 10 school principals as planned and one additional school principal, carried out using a questionnaire after the respondent tried to use the learning supervision observation application version 1.0 (AOS_versi 1.0).

The dissemination stage is carried out by uploading the observation application and its guidance to cyberspace so that this application program can be downloaded and used by those in need.

\section{Discussion}

Based on the test results in the implementation process above, the following results were obtained in Table 7.

Table 7. Implementation results

\begin{tabular}{|c|c|c|c|}
\hline Indicator & Total Score & Average Score & Category \\
\hline Material Aspect & 509 & 4.63 & Very worthy \\
\hline Results Aspect & 407 & 4.63 & Very worthy \\
\hline Language Aspect & 100 & 4.55 & Very worthy \\
\hline Aspects of Implementation & 347 & 4.51 & Very worthy \\
\hline Software Engineering Aspects & 500 & 4.55 & Very worthy \\
\hline Design Aspects & 104 & 4.73 & Very worthy \\
\hline Visual Communication Aspects & 50 & 4.55 & Very worthy \\
\hline Average & 2017 & 4.59 & Very worthy \\
\hline
\end{tabular}

Referring to Table 7, the learning supervision aspect has an index of 4.63 or greater than 4.2 , so it gets a very feasible category which means that the instruments used in the application are in accordance with what is needed. The resulting aspect has an index of 4.63 or greater than 4.2, so it gets a very decent category, meaning that the calculation results or output of the application are correct and documented automatically. The language aspect has an index of 4.55 or greater than 4.2 , so it gets a very decent category, the terms on the instrument and the application are easy to understand. The implementation aspect has an index of 4.51 or greater than 4.2 so it gets a very feasible category, the software engineering aspect has an index of 4.55 or greater than 4.2 then it gets a very decent category, meaning that the application is less than $10 \mathrm{MB}$ in size, easy to install, easy to use and can be used in various types of Android smartphones. The design aspect has an index of 4.73 or greater than 4.2 , so it gets a very decent category, meaning 
that users feel comfortable with the appearance of the application. The visual communication aspect has an index of 4.55 or greater than 4.2 so it gets a very decent category, meaning that this application is user friendly or easy to use.

\section{Conclussion}

The Android-based instrument application model has a feasibility index of 4.57 which means that it is very suitable for use in the learning supervision process, and can meet the kaizen principle of quality improvement (easier, better, faster, cheaper and simpler) when compared to the model developed. The output of this model can be used as a reference in determining the appropriate guidance for teachers so that the quality of the learning process and student learning outcomes can be improved to realize the goals of national education.

\section{Acknowledgments}

The author expresses his gratitude to the Chancellors of Pakuan University and the Pakuan Foundation through LPPM who have participated in financing this research.

\section{References}

Anggraeni, S. A., Amelia, I., Wulandari, P., Oktavianingrum, R., Adha, M. A., \& Gunawan, R. M. (2020, December). The Efforts of School Principal in Improving Quality of Learning Through Non-Thematic Learning Supervision in Elementary School. In 6th International Conference on Education and Technology (ICET 2020) (pp. 346-350). Atlantis Press.

Felker, D. (2010). Android application development for dummies. New York: John Wiley \& Sons.

Galitz, W. O. (2002). The Essential Guide to An Introduction to GUI Design Principles and Techniques, 2nd Editio. Canada: Wiley Computier Publishing.

Garrett, J. J. (2006). Customer loyalty and the elements of user experience. Design management review, 17(1), 35-39.

Kim, J. Y. (2018). A study on UX design process lecture based on modified PBL (problem-based learning). Journal of the Korea Convergence Society, 9(1), 117-131.

Lessing, A. C., \& Schulze, S. (2002). Postgraduate supervision and academic support: students' perceptions. South African Journal of Higher Education, 16(2), 139-149.

Liu, J., Lin, C. H., Potter, P., Hasson, E. P., Barnett, Z. D., \& Singleton, M. (2013, March). Going mobile with app inventor for android: a one-week computing workshop for K-12 teachers. In Proceeding of the 44th ACM technical symposium on Computer science education (pp. 433-438).

Makin, M., Abdullah, Z., \& Shafee, S. (2018). The art of supervision: Role of supervisory skills in developing teacher capacity. MOJEM: Malaysian Online Journal of Educational Management, 6(4), 37-55.

McCallin, A., \& Nayar, S. (2012). Postgraduate research supervision: A critical review of current practice. Teaching in Higher Education, 17(1), 63-74.

Meier, R. (2012). Professional Android 4 application development. John Wiley \& Sons.

Mukaromah, S., Kusumantara, P. M., Putra, A. B., \& Pratama, A. (2018, December). Analysis and Design Logbook Information Systems. In International Conference on Science and Technology (ICST 2018). Atlantis Press.

Pratama, A., Mukaromah, S., Ithriah, S. A., \& Safitri, E. M. (2020, July). Entrepreneurship Information System Design with ICONIX Process for a Student Business Unit Marketplace. In Journal of Physics: Conference Series (Vol. 1569, No. 2, p. 022041). IOP Publishing.

Pratiwi, F. D., Gunawan, I., Mahardika, B. A., Cahyaning, C. N., Amaliah, P. U., Adha, M. A., \& Lestari, S. P. (2020, December). Principal's Role in Thematic Learning Supervision That Works in Elementary School. In 6th International Conference on Education and Technology (ICET 2020) (pp. 176-181). Atlantis Press.

Saiedian, H., \& Dale, R. (2000). Requirements engineering: making the connection between the software developer and customer. Information and software technology, 42(6), 419-428. 
Siau, K., Erickson, J., \& Lee, L. (2005). Theoretical vs. practical complexity: The case of UML. Journal of Database Management (JDM), 16(3), 40-57.

Thakral, S. (2015). The historical context of modern concept of supervision. Journal of Emerging Trends in Educational Research and Policy Studies, 6(1), 79-88.

Wahyu, W. (2020). Concept of Supervision of Learning Process in Increasing the Quality of Education Results in Madrasah. International Journal of Nusantara Islam, 8(1), 67-77.

White, L., \& Allen, R. (2014). Using Google apps script for classroom management and more. Journal of Computing Sciences in Colleges, 30(2), 171-173. 